\title{
Factors Affecting Senior High School Students to Solve Three- Dimensional Geometry Problems
}

\author{
Fiki Alghadari ${ }^{1 *}$, Tatang Herman ${ }^{2}$, Sufyani Prabawanto ${ }^{2}$ \\ ${ }^{1}$ STKIP Kusuma Negara Jakarta, INDONESIA \\ ${ }^{2}$ Universitas Pendidikan Indonesia, INDONESIA \\ *CORRESPONDENCE: $₫$ alghar6450@gmail.com
}

\begin{abstract}
Geometry mastery is a must for high school students, affected by several factors such as learning approach (LA), gender, level of basic geometry competencies (BGC) and level of mathematical self-efficacy (MSE) among others. The purpose of this study is to examine those factors that affect the geometry problem solving (GPS) abilities of the students. This study involved 101 Indonesian high school students. They were divided into two groups based on the implemented LA, namely the investigative learning group and the direct instruction group. Data were collected through three instrument types, namely test of BGC, GPS, and MSE. The MSE scale consists of two models namely mathematics test-taking self-efficacy (MTSE) and mathematical skill self-efficacy (MSSE). Data were analyzed using ANOVA techniques, path analysis, and error analysis. The path diagram is MSE, which mediates the BGC effect on GPS. Data analysis results revealed that the level of BGC, MTSE as well as interactions between LA and gender had a significant impact on the GPS capability of students. In this case, the BGC of the students impacted their MSE and thus impaired their GPS skills, which also moderated the gender and learning. There are phases in the process of solving problems that tend to hamper student performance. The visualization process appears to be done by female students, while male students make representations when they do. The researchers, therefore, suggest further research related to gender-based LA study in the geometry curriculum to improve the ability of the students.
\end{abstract}

Keywords: basic geometry competencies, gender, learning approach, mathematical self-efficacy

\section{INTRODUCTION}

Report of the International Student Assessment Program (PISA) study shows that Indonesian students' geometry achievement is poor (OECD, 2013). This affects the attainment of geometry learning goals. In practice, learning about geometry was given to students in Indonesia starting from primary school. However, in the learning process, it seems only to meet the intended learning program according to the demands of the curriculum. Moreover, geometry is part of mathematics instruction and not a distinct subject in Indonesia's education curriculum. Mastery of tiered and interrelated concepts is required in geometry learning. Learning geometry at the high school level would require applying concepts taught at the prior educational level. This is a challenge for students, for instance, the concept of geometry taught at the junior high school level is the basic concept required to construct new schemes at a higher level.

There are several materials at the high school level which include the principle of geometry such as trigonometry at the high school 1st year, geometry transformation at the high school 2nd year, and three dimensions at the high school 3rd year. It highlights the fragmentation of ideas dependent upon the school

Article History: Received 14 July $2019 \bullet$ Revised 13 April $2020 \bullet$ Accepted 27 April 2020

(C) 2020 by the authors; licensee Modestum Ltd., UK. Open Access terms of the Creative Commons Attribution 4.0 International License (http://creativecommons.org/licenses/by/4.0/) apply. The license permits unrestricted use, distribution, and reproduction in any medium, on the condition that users give exact credit to the original author(s) and the source, provide a link to the Creative Commons license, and indicate if they made any changes. 
level's working time settings. However, there are some drawbacks to the learning context. The presented material rarely includes the three-dimensional building function into the application of the trigonometric learning concept. Furthermore, the concept learned in learning geometry transformation is about transforming a geometric shape in the coordinate plane so its implementation relies on moving from a shape to a shadow. This causes students' difficulties in understanding the knowledge connection that is understood to the concepts used to work on the problem, or students know the details and concepts to be used but lack to connect the basic concepts of geometry with the concepts they have just studied (Alghadari \& Herman, 2018). This reflects the unsynchronization of various concepts that have been used. The concepts used are not complementary to correctly deal with the problem. Furthermore, Rosilawati and Alghadari (2018) claimed that errors may also occur when students are not referring to the concept of prerequisite geometry. Teachers must be able to prepare the scattered information of the students in order to create nodes between concepts in their cognitive schemes. This is significant because the learning condition has a strong influence on how students perceive mathematical concepts interpreted (Rahayu \& Alghadari, 2019; Setiadi, Suryadi \& Mulyana, 2017).

The element in three-dimensional geometry is a subset of field geometry. Understanding geometry as an abstract representation of the concept is always related to visual form. Spatial context often includes in the study of geometry. Learning plane geometry also requires a spatial understanding, and gender variables are good predictors of spatial issues (Alghadari, 2016; Goos, Stillman, \& Vale, 2017). Competent success is however created because students have the requisite skills to succeed (Cetin, Erel, \& Ozalp, 2018), and students “ knowledge and skills will not eventually succeed if they don't have faith in themselves (Aurah, Cassady, \& McConnell, 2014). Self-confidence is the incentive to not give up quickly, to solve problems and to be courageous when dealing with issues, while knowing the risks of difficulties (Skaalvik, Federici, \& Klassen, 2015). Motivational indicators are components of self-efficacy (Zhang, 2017a). Therefore, GPS is influenced by several factors both directly and indirectly.

\section{LITERATURE REVIEW}

\section{Geometry Learning in Senior High School Context}

Nowadays, technology has been frequently functioned in learning mathematics. Technology is undeniably suggested to apply due to its easy and dynamic geometry image visualization, so that it provides geometry familiarity for students. In the practice, technology functions only for some learning activity parts, for students should apply geometry transformations to other media; media changing occurs, from screen technology to paper. In addition to that, some studies from Alghadari and Herman (2018), and Rosilawati and Alghadari (2018) reported that learning geometry either focuses on visualization and abstraction, or geometry problem solving which effectuated by fallacy of basic concept understanding complexity, while the combination of concept is mathematical principle to find solution. Nonetheless, some studies reports mentioned that gender factor is a strong predictor in visual-spatial issue, in which man's skill is a lot better compared to woman's (Buckley et al., 2019; Goos et al., 2017). A number of reasons of technology application in learning are identified, and those have been highlighted by Hathaway and Norton (2018). First, in Mathematics education program, effective technology application in class has not been taught, therefore ability and knowledge of technology application are necessary. Second, class does not indicate readiness to use technology effectively as a patron to learning. Third, most of research only portray the best strategies to apply technology; only a few display evaluation process. Technology inarguably becomes relative to use in learning, but its specific effects have not been revealed. Sinclair et al. (2016) affirmed that technology use in geometry learning is not relevant as long as students' evaluation system is not integrated in the tools. In Indonesia, technology is rarely applied in geometry concept test.

Additionally, learning boundary is also a concern, why geometry learning has not been supported by technology. In this case, educational facility remains the most decisive issue as its relation with teacher's professional and pedagogic competence in rural and urban areas (Ardika, Sitawati, \& Suciani, 2013), for instance, minimum facility for teaching and learning (Prawoto \& Basuki, 2016); this study was conducted in a remote area, a bit far from the capital city. Those mentioned reasons direct us to an assumption that it is acceptable why direct learning dominates geometry learning in high school (Alghadari, Turmudi, \& Herman, 2018). In general, such learning utilizes teacher's potential and competence as the one and only information source to transfer knowledge to all students in class. Substantially, direct learning only suits one particular learning; it depends on students' characteristics, and it still needs students' prerequisite skill in the practice 
(Wieber et al., 2017). With this approach, students construct concept after teacher knowledge with their different cognitive ability, which is based on thinking level and concept mastery. Recently, feature of effective geometry learning is to push students to investigate, explore relation, and acknowledge varieties of category, orientation, and size to provide geometric experience (Clements \& Sarama, 2009). Such a learning process is suitable with fallibly perspective, to re-invent mathematical ideas through knowledge construction taking place in cognitive area (Ernest, 1991). By implementing such process, students are expected to have ability and work consistency to solve any kinds of geometry problem. Sumarna, Wahyudin, and Herman (2017) concluded this in their study that investigative learning promotes students' ability to solve problems.

\section{Geometry Thinking, Problem-Solving and Mathematical Self-Efficacy}

Students' learning objective of geometry concept is to equip them with ability to see benefit of geometry concept and how the concept is implemented in line with context. The context here is interpreted as a situation when solving problems give implication to acquire new knowledge. There is a binding definition and related to new knowledge acquired, that not all questions are stated as problems, they are not something routine and intellectual challenges (Dossey, 2017). This further means that the process shall engage thinking ability to conceptualize a solution. In solving geometry problems, geometry thinking should be first operated even before mathematical computation is applied. Geometry thinking is classified into some hierarchy levels, and those levels are delineated as development level of geometry thinking according to Van Hiele's theory. Those levels are visualization (recognition), analysis, abstraction, deduction, rigor (Dindyal, 2015; Goos et al., 2017). Herbst et al. (2017) have conveyed that one of thinking processes in geometry problem solving is interpreting 3D shape representation. This process absolutely does not put geometry or mathematic concepts aside, and it points out that interpreting shape involves concept realization, while concept realization, geometry fact or arithmetic is processes to solve problems (Dindyal, 2015).

Definition of problem implicates directly to level of difficulty of something to achieve. To that end, there are two things as a content domain to solve problems, they are dependability and stability; they are a part of perseverance. Perseverance has correlation with confidence towards the ability to get the right answer (Dossey, 2017), and this becomes one point of view of motivation aspect. Motive underpinning the two functions is achievement, so that motivation walks in line with investigation and problem solving. In short, there is a connection among problems, problem solving, investigation, and motivation aspect. There are some variables in specific domain categories that included into motivation aspect, such as determination and risk-taking, in which those aspects are a part of self-efficacy (Zhang, 2017a). On that ground, self-efficacy emerges as the main motivation variable to predict effort, persistence, and perseverance performed to solve a task (Lishinski, Yadav, Good, \& Enbody, 2016; Silk \& Parrott, 2014). This specific domain is one of the strongest predictors and can be relied on for the success of problem solving (Aurah et al., 2014), and compared to other specific domains, assessment of self-efficacy to solve problems is regarded more predictable by individual (Zhang, 2017a). Schunk and Dibenedetto (2016) added that one model related to problem solving is self-efficacy for performance. In Collins, Usher, and Butz (2015), self-efficacy is viewed as a model of mathematics test-taking self-efficacy. Likewise, self-efficacy is based on belief in self-competence, and such a model has been listed in Street, Malmberg, and Stylianides (2017) which is then called mathematics skill self-efficacy.

\section{PURPOSE OF THE STUDY AND RESEARCH QUESTION}

Regarding the objective of geometry learning in senior high school curriculum, and some related factors to affect students' geometry problem solving, such as: LA, gender, BGC and MSE, the present research aims at analyzing those mentioned factors. To be more specific, the research is intent on answering these following questions: (1) What factors do affect students in solving geometry problems?; (2) What process does prevent students from solving the problems?

\section{METHODOLOGY}

\section{Design and Participants}

The present research analyzed factors affecting GPS, comprising of LA, gender, BGC, and MSE level, either in partial or in a whole. The present research was designed by implementing two LA. These two LA were intended for 2 groups from 101 participants. The samples were all students of XII grade of Senior High School Academic Year 2018/2019 in a regency of Bangka Belitung province, Indonesia. The sample number was 
considered relatively big for a province with low population. The samples were divided into two. One group learned geometry using investigative learning; this group consisted of 58 students, 33 male and 25 female students. Another group learned geometry using direct learning, this group comprised of 43 students with 16 male and 27 female students. All samples listed were the respondents for the present research's data source.

\section{Learning Implementation}

Investigative learning in the present research is the modification of a model designed by Yeo $(2013,2017)$. The modification was performed as its design is a process of learning and solving arithmetic problems. For the present research's focus was geometry, some different processes in investigating were identified. Some steps suggested by the theory were still adapted, for instance entry-attack-review-extension. However, the modification was carried on the attack phase, implemented by the involvement of visualization, organization, representation, and application process so that is producing a product of though. The process of organization and visualization can both start and it is because of the solved geometry problem model. The four processes were developed based on some models of geometry problem solving alternative referring to five levels of Van Hiele theory and some literature review from Dindyal (2015) and Herbst et al. (2017). The students taught by direct learning were treated by some processes which were dominated by the teacher based on the theory of Arends (2015), they were establishing set, explanation or demonstration, guided practice, feedback, and extended practice. The two approaches show different implementation since investigation learning is a dominant model for students' activity, while in direct learning, activity is given by facilitator. Even so, principally, when students solve their problems, investigation process is involved.

\section{Test Instrument}

Quantitative data were collected from test of BGC, GPS and student MSE scale response. MSE scale was completed by the students before they finished the problem of geometry. There were six questions of GPS test developed based on aspect of Polya's problem solving and Van Hiele's geometry thinking. Afterwards, there were 20 items of MSE scale, divided into two scale models, adapted from Silk and Parrott (2014), they were 10 items for mathematics test-taking self-efficacy (MTSE) scale and the rest was mathematics skill selfefficacy (MSSE) scale. MSE instrument was set in differential semantic with interval 0-10. MTSE scale was generated by the involvement of item content in GPS test. The content was inserted regarding the students' indicator to assign responses of their self-efficacy of being able to solve the problems. To determine the responses, the students would not certainly discharge from their BGC role as a dimension to show that they had capacity to solve the problem on the item content. On the other hand, BGC was enfolded in mastery experience as a source of self-efficacy. For that reason, this study measured BGC due to its indirect role behind self-efficacy. In this context, BGC was measured by three indicators of geometry basic competence, in Mathematics curriculum standard for senior high school students. MTSE is different from MSSE scale in terms of deep substance. The test item content being involved in the scale as the students' indicator to determine their belief to solve the problem based on their skill, would not be loaded in the test of GPS measurement. Both MTSE and MSSE, based on their theory, are categorized into self-efficacy generated from mastery experiences (Silk \& Parrott, 2014).

\section{Data Analysis}

Having implemented the learning program, some instruments were given to the students to obtain quantitative data. BGC test was administered to collect their score and then be analyzed to group the high, middle and low achievers; those categorized into middle achievers had interval between the reduced average and added by deviation standard. From the analysis of investigative learning, it was gained 12 students for high achievers, 38 for middle achievers, and 8 for low achievers category. While for the students treated by direct learning, it was found there were 10 higher achievers, 23 middle achievers, and 8 lower achievers. In the next step, the students faced MSE and GPS test. MSE scale test was carried out earlier than the GPS test. Here, different technique was applied, as MSE and its two models were only based on high and low category. The categorization was set substantially that the high achievers got score above average. BGC had no middle achiever category, as the number of students was not proportional when applying average score and deviation standard in the categorization. The sample numbers did not meet the requirement to display three levels of MSE levelling score. From the whole MSE score analysis, MTSE and MSEE, the average found was 94,422; 52,031 and 42,391 . Therefore, the numbers of student in the high and low category in serial were 50 and 51 , 48 and 53, 54 and 47 students. The functions of this categorization were to perform two-way data analysis of variance and proceed to path analysis. 


\section{RESULTS}

The following is the descriptive statistics of data analysis result of BGC, MTSE, MSSE, MSE and GPS. Table 1 displays the details of average and deviation standard.

Table 1. Students' Achievement in Geometry Learning

\begin{tabular}{ccccccccc}
\hline \multirow{2}{*}{ Data } & \multirow{2}{*}{ Statistics } & \multicolumn{2}{c}{ LA } & \multicolumn{2}{c}{ Gender } & \multicolumn{3}{c}{ Categories } \\
\cline { 3 - 9 } & & Investigative & Direct & Male & Female & High & Medium & Low \\
\hline \multirow{2}{*}{ BGC } & Mean & 43.750 & 63.256 & 50.102 & 53.894 & 60.796 & 51.393 & 43.611 \\
\cline { 2 - 9 } & Stdev & 24.514 & 31.199 & 28.840 & 29.453 & 27.981 & 28.418 & 31.286 \\
\hline \multirow{2}{*}{ MTSE } & Mean & 49.786 & 55.058 & 55.749 & 48.527 & 65.737 & - & 39.617 \\
\cline { 2 - 9 } & Stdev & 22.327 & 17.074 & 22.347 & 17.744 & 16.120 & - & 15.156 \\
\hline \multirow{2}{*}{ MSSE } & Mean & 42.151 & 42.716 & 45.656 & 39.315 & 49.132 & - & 34.648 \\
\cline { 2 - 9 } & Stdev & 21.872 & 13.103 & 20.903 & 15.655 & 17.807 & - & 16.424 \\
\hline \multirow{2}{*}{ MSE } & Mean & 91.937 & 97.774 & 101.405 & 87.843 & 116.378 & - & 72.897 \\
\cline { 2 - 9 } & Stdev & 43.037 & 27.388 & 41.185 & 31.889 & 31.089 & - & 29.267 \\
\hline \multirow{2}{*}{ GPS } & Mean & 9.276 & 8.791 & 9.286 & 8.865 & 12.091 & 8.820 & 6.222 \\
\cline { 2 - 9 } & Stdev & 3.883 & 3.214 & 3.862 & 4.068 & 4.242 & 3.462 & 2.625 \\
\hline \multirow{2}{*}{ Thea }
\end{tabular}

The ideal score of BGC=100, MTSE=100, MSSE=100, MSE=200, and GPS=34

Some points are highlighted based on Table 1. First, the mean of students' GPS test in investigative learning is higher than direct learning group's score although another average score seemed to be lower. Second, only BGC score average shows the female students achieve more than the male students do. This means that the female students have much better ability to solve problems referring to mathematic education curriculum standard. Third, each factor indicates no one includes in higher achievers with the average achievement lower than middle or low category. Here, the researchers view that in whole, students' BGC score is no more than $64 \%$, while the GPS score is no more than $36 \%$. However, for the last score, it is considered fine as PISA survey 2012 (OECD, 2013) reported that Indonesian students' geometry achievement at age 15 is about $38.3 \%$. By looking at the indicator, the researchers are convinced to analyze students' geometry achievement based on some factors, which are theoretically and empirically proven to give effect. The following is data analysis result that is presented differently based on the main effect and interaction.

Table 2 quantitatively signifies that BGC, MSE and one model of MTSE and interaction between LA and gender, affect students' ability to solve geometry problems significantly. To justify the analysis, some relevant studies are presented. Having knowledge and skill will not result in qualified problem solving once selfconfidence to utilize the resources does not exist (Aurah et al., 2014). Self-confidence can become motivation to be determined and able to solve the problems faced, even to have courage for solving challenging mathematic problems although the difficult risks are real (Skaalvik et al., 2015). The constructs are self-efficacy aspects as specific domain of motivation (Zhang, 2017a). Notwithstanding, there is no self-efficacy to result in competence unless students have required skill to succeed (Cetin et al., 2018). With this basis, the researchers continued the effect analysis of BGC and two MSE models on GPS. Based on the interaction effect between LA and gender, the analysis was applied considering the two moderators to their groups, by applying structure model test of BGC to GPS score mediated by MTSE score and MSSE. The summary analysis is displayed below.

Table 2. Main and Interaction Effect toward GPS

\begin{tabular}{cccccccc}
\hline \multicolumn{2}{c}{ Main Effect } & \multicolumn{3}{c}{ Interaction Effect } \\
\hline Resources & F & Sig. & $\begin{array}{c}\text { Adj. } \\
\text { R Squared }\end{array}$ & Resources & F & Sig. & $\begin{array}{c}\text { Adj. } \\
\text { R Squared }\end{array}$ \\
\hline BGC & 14.150 & $0.000^{*}$ & 0.208 & Gender \& LA & 13.144 & $0.000^{*}$ & 0.097 \\
\hline Gender & 0.283 & 0.596 & -0.007 & Gender \& BGC & 0.889 & 0.414 & 0.223 \\
\hline LA & 0.369 & 0.545 & -0.006 & Gender \& MTSE & 0.427 & 0.515 & 0.123 \\
\hline MTSE & 16.832 & $0.000^{*}$ & 0.137 & Gender \& MSSE & 0.252 & 0.617 & -0.020 \\
\hline MSSE & 0.590 & 0.444 & -0.004 & Gender \& MSE & 0.602 & 0.440 & 0.071 \\
\hline MSE & 10.123 & $0.002 *$ & 0.084 & & & & \\
\hline *
\end{tabular}

*Significant at level 0.05

Table 3 reveals that only for moderating variable male gender and instigative learning, BGC, MTSE and MSSE completely give significant effect on GPS. Furthermore, all MSSE effect on GPS is identified as negative, all effects of MTSE on GPS is significant, and only BGC effect (based on female gender) indicates insignificant effect on GPS. From MSSE negative effect on GPS, the researchers assume that students' GPS 
even predisposes MSSE. In this case, MTSE is the moderating key of motivation for student problem solving performance. The analysis notes lead to a conclusion that students' BGC has influenced self-efficacy for performance, so that it further affects GPS ability, which is then manifested in the students' certainty about the problem solving accuracy. Additionally, gender and learning factor strengthen it. Still and all, the researchers keep investigating why BGC does not infer significant effect on GPS based on female gender, so the researchers obtain detail percentage of students' tendency to solve problems regarding particular phase during the process of solving the problems, as illustrated below.

Table 3. The Effect of BGC on GPS and the Moderating Variable

\begin{tabular}{|c|c|c|c|c|c|c|}
\hline \multirow{2}{*}{$\begin{array}{c}\text { Moderating } \\
\text { Variable }\end{array}$} & \multirow{2}{*}{ Parameter } & \multicolumn{3}{|c|}{ Effect } & \multirow{2}{*}{ t-value } & \multirow{2}{*}{ R-Square } \\
\hline & & Direct & Indirect & Total & & \\
\hline \multirow{5}{*}{ Male gender } & $\mathrm{BGC} \rightarrow \mathrm{MTSE}$ & 0.389 & - & 0.389 & $3.547^{*}$ & 0.210 \\
\hline & $\mathrm{BGC} \rightarrow \mathrm{MSSE}$ & 0.218 & - & 0.218 & $1.961^{*}$ & 0.076 \\
\hline & $\mathrm{BGC} \rightarrow \mathrm{GPS}$ & 0.050 & 0.035 & 0.085 & $2.526^{*}$ & \multirow{3}{*}{0.480} \\
\hline & $\mathrm{MTSE} \rightarrow \mathrm{GPS}$ & 0.097 & - & 0.097 & $4.239^{*}$ & \\
\hline & $\mathrm{MSSE} \rightarrow \mathrm{GPS}$ & -0.060 & - & -0.060 & $-2.684^{*}$ & \\
\hline \multirow{5}{*}{ Female gender } & $\mathrm{BGC} \rightarrow \mathrm{MTSE}$ & 0.220 & - & 0.220 & $2.768^{*}$ & 0.130 \\
\hline & $\mathrm{BGC} \rightarrow \mathrm{MSSE}$ & 0.160 & - & 0.160 & $2.223^{*}$ & 0.090 \\
\hline & $\mathrm{BGC} \rightarrow \mathrm{GPS}$ & 0.035 & 0.017 & 0.052 & 1.821 & \multirow{3}{*}{0.260} \\
\hline & $\mathrm{MTSE} \rightarrow \mathrm{GPS}$ & 0.089 & - & 0.089 & $2.934^{*}$ & \\
\hline & $\mathrm{MSSE} \rightarrow \mathrm{GPS}$ & -0.018 & - & -0.018 & -0.548 & \\
\hline \multirow{5}{*}{$\begin{array}{l}\text { Investigative } \\
\text { Learning }\end{array}$} & $\mathrm{BGC} \rightarrow \mathrm{MTSE}$ & 0.470 & - & 0.470 & $4.513^{*}$ & 0.270 \\
\hline & $\mathrm{BGC} \rightarrow \mathrm{MSSE}$ & 0.380 & - & 0.380 & $3.557^{*}$ & 0.180 \\
\hline & $\mathrm{BGC} \rightarrow \mathrm{GPS}$ & 0.067 & 0.039 & 0.106 & $3.223^{*}$ & \multirow{3}{*}{0.470} \\
\hline & MTSE $\rightarrow$ GPS & 0.084 & - & 0.084 & $3.957^{*}$ & \\
\hline & $\mathrm{MSSE} \rightarrow \mathrm{GPS}$ & -0.043 & - & -0.043 & $-2.071^{*}$ & \\
\hline \multirow{5}{*}{ Direct Learning } & $\mathrm{BGC} \rightarrow \mathrm{MTSE}$ & 0.026 & - & 0.026 & 0.304 & 0.002 \\
\hline & $\mathrm{BGC} \rightarrow \mathrm{MSSE}$ & -0.042 & - & -0.042 & -0.650 & 0.010 \\
\hline & $\mathrm{BGC} \rightarrow \mathrm{GPS}$ & 0.036 & 0.006 & 0.042 & $2.091^{*}$ & \multirow{3}{*}{0.380} \\
\hline & $\mathrm{MTSE} \rightarrow \mathrm{GPS}$ & 0.128 & - & 0.130 & $4.093^{*}$ & \\
\hline & $\mathrm{MSSE} \rightarrow \mathrm{GPS}$ & -0.075 & - & -0.075 & -1.822 & \\
\hline
\end{tabular}

*Significant at level 0.05

In Figure 1, Inv-M signs the male students and Inv-F for the female students in investigative learning, whereas Drc-M refers to the male students and DRc-F indicates the female students in direct learning. For example, in investigative learning, serially $35,4 \%$ and $36,4 \%$ male students find difficulties in visualization and representation in solving geometry problems. The percentage is obtained from the comparison between the students who do mistakes and the student total numbers in the group, so the researchers propose that the percentage represents obstacle tendency faced by the students while doing adjustment to solving process in investigative learning (organization-visualization-representation-concept application). The solving process is based on Zhang's theory (Zhang, 2017b) that during direct learning implementation, class activity tends to be teacher-centered so that in the present research context, students' BGC should be optimally utilized when they explore and solve the non-routine geometry problems. In other words, the students from direct learning group also perform investigation although it is not their habit to be projected to work hard and survive. 


\section{Trend percentage of student's obstacles}

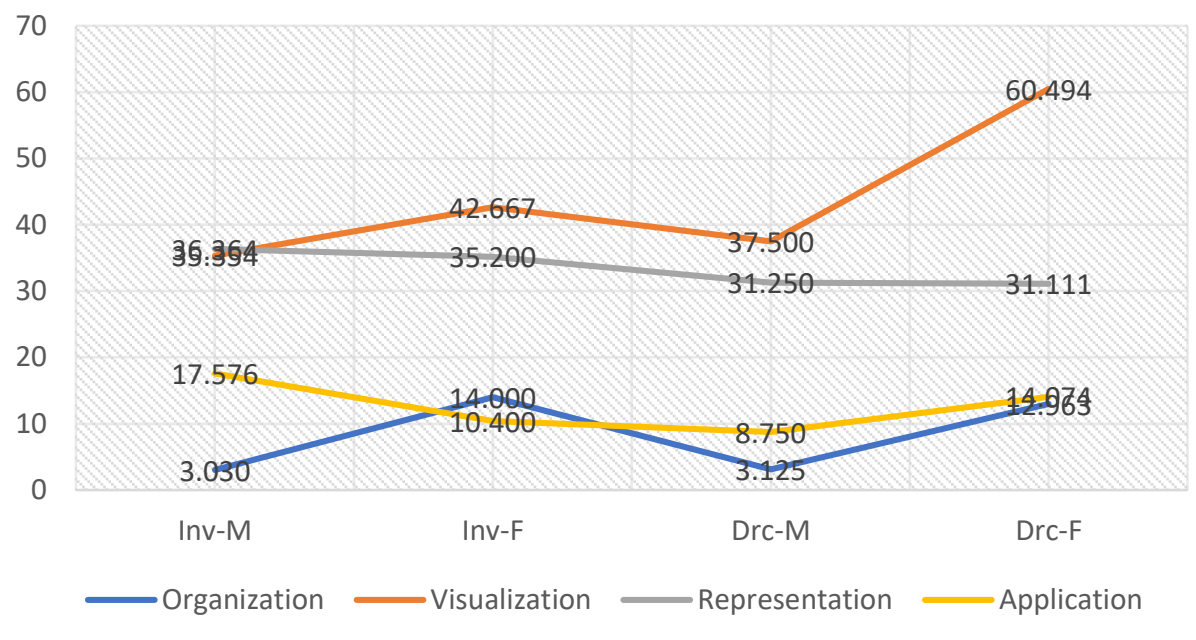

Figure 1. Trend percentage based on LA and gender

The figure unveils some information relating to an analysis in the previous part. First, the female students have bigger chances to experience obstacles in the terms of organization and visualization compared to male students. Two contexts for the further obstacles, representation and application, are the rest of the percentage aside from those who answer true or do not provide answers. Second, the female students from direct learning encounter more barriers in visualization compared to other students from investigative learning. Third, the male students from investigative learning find difficulties in representation and visualization to solve problems. Fourth, the male students from direct learning group are in difficulties of visualization and representation.

\section{DISCUSSION}

Talking about learning on geometry concept, especially distance in three dimensions, will emerge different perception and learning experience among people. As geometry orientation is visual-spatial, explicitly it has burdened on strategy of abstract spatial reasoning by understanding problems and manipulating information (Buckley, Seery, \& Canty, 2019). Thus, solving geometry problems in its context required visualization-spatial and spatial-transformation (Rosilawati \& Alghadari, 2018), as the process of spatiality is implemented earlier than mathematic ability (Alghadari, 2016). For the requirement mentioned above, it has been declared that gender factor is a strong predictor in spatial issue due to some study reports underlining that man's ability is a lot better than woman's (Buckley et al., 2019; Goos et al., 2017). Further, gender factor influences students' self-efficacy (Schunk \& Dibenedetto, 2016), and gender is a significant moderator to govern basic competence on self-efficacy directing to mathematic achievement (Chang, 2015; Grigg, Perera, McIlveen, \& Svetleff, 2018). All factors listed above have been a part of the present research. Hereinafter, the fact speaks that based on the average of achievement, there is score increase as the result of geometry competence and learning approach. It is geometry basic and problem solving competence for each learning approach to place higher position. The researchers denote that learning habit implemented in the approach is the reason.

During the implementation of direct learning, problem-solving process suiting the curriculum standard tends to be taught to students, as the textbook usually contain questions to apply aspect of cognitive process dimension. For that reason, in direct learning group, it is acceptable to see the female students' competence on geometry is much higher than the male students' competence. The bigger female student number also supports this different score. To explain this phenomenon, the researchers see the analysis result for trend percentage of students' obstacle, finding out that there is a much higher tendency of male students in investigative learning to encounter obstacles in applying concept compared to female students (after visualization and representation process). Moreover, the male student composition in the investigative learning group is more than the female student number; it is vice versa in the direct learning group. This result exhibits different view from the discussion of Alghadari and Herman's study (2018) as the students do not go through verbal and communication barriers in interpreting information, concept, and problems to finish. Howbeit, in both groups, the female students specifically tend to find difficulties in visualization while 
the male students are interrupted by representation. Yet, as acknowledged by Buckley et al. (2019) and Goos, et al. (2017), higher ability of male students is determined by trend percentage of student obstacles, as in investigative learning, representation is applied after visualization.

Further, learning to enrich the effect of performance in mathematics with MSE is the main mediator factor (Zhang, 2017a); gender also moderates the effect (Lishinski et al., 2016), the two seem to appear in late teenager age (Huang, Zhang, \& Hudson, 2018). To go further, self-efficacy is a mediator for mathematic achievement (Grigg et al., 2018; Xu \& Jang, 2017), and mediates students to solve problems (Bhowmick, Young, Clark \& Bhowmick, 2017). Seeing all the justifications, the result of this study clarifies that selfefficacy is a mediator factor, but the detail is only for performance-based self-efficacy, which is well-known by mathematics test-taking self-efficacy. Such efficacy test even displays its effect on the inverse GPS. In connection with that type, Cetin et al. (2018) corroborated there is a negative significant correlation between self-efficacy and problem solving, and Lishinski et al. (2016) reported that there is reciprocal effect between performance for mathematics and self-efficacy. Factually, it is right to say that being able to solve problems shall influence student self-efficacy capacity. Accordingly, the reciprocal shows negative effect of mathematics skill self-efficacy on geometry problem solving, so that theoretical aspect with the empirical basis contributes to the present research accuracy.

In other studies, Aurah et al. (2014) have explicated that self-efficacy can be reckoned for problem solving success. Silk and Parrott (2014) have published their findings that self-efficacy as a form of affective attitude, has given independent contribution to problem solving. Those mentioned findings designate the effect of selfefficacy on problem solving, and in specific context of this present research, the finding denotes that mathematics test-taking self-efficacy influences geometry problem solving. Still, the students' low achievement requires further need analysis, although indicators of PISA study result can analyze the achievement. Practically, this is what occurs and has been a concern of the researchers during the implementation process of LA. Student learning habit is the main reason. Again, one of the findings portrays the students' obstacles in visualization due to spatial element of geometry. Buckley et al. (2019) and Zhang (2017b) have underlined that spatial barrier may prevent students from mastering mathematical concept in which they have not acquired salient content to pass the standard of spatial ability. Such ability is pivotal regarding working memory capacity and cognitive burden induced by the problems. In this case, visualization plays a prominent role to explicate, analyze, and conclude geometric relation (Fan, Mailizar, Alafaleq, \& Wang, 2018). The theory is the justification for the researchers' assumption about why the female students are more convenient to direct learning than investigative in learning geometry. Although each learning and gender point out no significant difference and student learning obstacles, they do not against the statistical hypothesis testing which declares there is an influence of interaction between learning and gender on students' ability achievement to solve geometry problems.

Nowaday, learning geometry has not really based technology applications to assist students in the process of transferring or finding knowledge (Hathaway \& Norton, 2018). Some educational studies also still leave reports that the achievement of the geometry of one gender trait is more than another (Alghadari, 2016; Goos et al., 2017). On the other hand, the skills to operate the functions of various technology applications must also be mastered by teachers and students while the number of class meeting hours is not provided for this purpose. Students are used to using technology in their lives and it seems they are also enthusiastic, but their skills are not widely trained to solve academic-based problems. Then, in the context of learning only a few schools learn to separate students by gender. However, the gender category in this study is only on the masculine and feminine nature due to the small number of samples having the same characteristics in one region so that it becomes a limitation of the study. Another limitation is that student BGA is only measured based on students' ability to apply the Pythagorean theorem to calculate geometry concepts in geometric shapes while geometry concepts in problem solving also involve the concept of parallel lines and comparisons. However, according to the results of this study and its contribution to science, by not involving the technological function that the learning process is differentiated by gender in the education curriculum becomes a recommendation for better student achievement in geometry classes. Furthermore, the learning process of geometry or generally mathematics, how students and their conditions, learning does not release the role of self-investigation in an effort to find knowledge and understand concepts. Therefore, the learning process that accustoms students to investigate is a need at the organization, visualization, and representation stages, as well as facilitating them to internalize mathematical concepts. Investigating and solving problems are both aimed at gaining knowledge. In solving problems, students also involve their creativity. Creativity quotient is a research base of Romey (1970) which prepares educators' knowledge to use a curriculum designed 
to help students learn to find their own ways of formulating hypotheses and generalizations so that they will complete each learning unit with sincere feelings because they have found or created ideas for themselves alone. The research base is the beginning of investigative teaching.

\section{CONCLUSION}

The data analysis directs to a conclusion that BGC, MSE and one model of mathematic test-taking, and interaction between gender and learning, have significantly predisposed geometry problem solving. Then, either being moderated by learning or gender, there is a significant effect of BGC, MTSE and MSSE on geometry problem solving. In this field, MTSE is a key mediator factor influencing geometry problem solving. Nevertheless, MSSE sways negatively geometry problem solving. Thereupon, the students' BGC affects MTSE and GPS, which causes self-efficacy on the task they work on. Even so, some factors mentioned do not touch geometry problem solving substantially. It occurs due to the students' low achievement which produced by visualization barrier, in which the female students face more difficulties than the male students do. The female students from direct learning are categorized as the one who find the most visualization barrier. Some studies report the students' different ability seen from LA and gender. Students' ability and accuracy to solve problems have made an impact on their self-efficacy and geometry achievement. Hence, LA and gender are the factor moderating students' BGC and efficacy. Consequently, the present research recommends LA adjustment to gender as the visualization process becomes the main obstacle preventing the students from geometry material mastery.

\section{ACKNOWLEDGEMENT}

This research funding was supported by The Ministry of Research, Technology, and Higher Education and Indonesia Endowment Fund for Education under grant FR1182018150215.

\section{Disclosure statement}

No potential conflict of interest was reported by the authors.

\section{Notes on contributors}

Fiki Alghadari - STKIP Kusuma Negara Jakarta, Indonesia.

Tatang Herman - Universitas Pendidikan Indonesia, Indonesia.

Sufyani Prabawanto - Universitas Pendidikan Indonesia, Indonesia.

\section{REFERENCES}

Alghadari, F. (2016). Pemecahan Masalah Spasial Matematis Calon Guru Matematika Ditinjau dari Langkahlangkah Pemecahan Masalah Polya. Jurnal Penelitian Pendidikan, 16(3), 226-234.

Alghadari, F., \& Herman, T. (2018). The obstacles of geometric problem-solving on solid with vector and triangle approach. Journal of Physics: Conference Series, 1132(1), 012046. https://doi.org/10.1088/17426596/1132/1/012046

Alghadari, F., Turmudi, T., \& Herman, T. (2018). The application of vector concepts on two skew lines. Journal of Physics: Conference Series, 948(1), 012030. https://oi.org/10.1088/1742-6596/948/1/012030

Ardika, I. W. D., Sitawati, A. A. R., \& Suciani, N. K. (2013). Fenomena Pokok Pendidikan Indonesia: Apa dan Bagaimana? Jurnal Sosial Dan Humaniora, 3(1), 96-107.

Arends, R. I. (2015). Learning to Teach (10th ed.; P. Braffman, Ed.). New York, NY: McGraw-Hill Education.

Aurah, C., Cassady, J. C., \& McConnell, T. (2014). Predicting Problem Solving Ability from Metacognition and Self-Efficacy Beliefs on a Cross Validated Sample. British Journal of Education, 2(1), 49-70.

Bhowmick, S., Young, J. A., Clark, P. W., \& Bhowmick, N. (2017). Marketing Students' Mathematics Performance: The Mediating Role of Math Anxiety on Math Self-Concept and Math Self-Efficacy. Journal of Higher Education Theory \& Practice, 17(9), 104-117. https://doi.org/10.33423/jhetp.v17i9.1426 
Buckley, J., Seery, N., \& Canty, D. (2019). Investigating the use of spatial reasoning strategies in geometric problem solving. International Journal of Technology and Design Education, 29(2), 341-362. https://doi.org/10.1007/s10798-018-9446-3

Cetin, S. Y., Erel, S., \& Ozalp, O. (2018). Assessment of problem solving proficiencies with self-efficacy perceptions of students in faculty of health sciences of cyprus international university. SHS Web of Conferences, 48(1), 01025. https://doi.org/10.1051/shsconf/20184801025

Chang, Y. L. (2015). Examining relationships among elementary mathematics teachers' efficacy and their students' mathematics self-efficacy and achievement. Eurasia Journal of Mathematics, Science and Technology Education, 11(6), 1307-1320. https://doi.org/10.12973/eurasia.2015.1387a

Clements, D. H., \& Sarama, J. (2009). Learning and Teaching Early Math. New York: Routledge.

Collins, J. S., Usher, E. L., \& Butz, A. (2015). Examining Students' Perceived Autonomy Support as a Source of Self-Efficacy in Mathematics. Poster Session Presented at the Annual Meeting of the American Education Research Association, 1.

Dindyal, J. (2015). Geometry in the early years: a commentary. ZDM, 47(3), 519-529. https://doi.org/10.1007/s11858-015-0700-9

Dossey, J. A. (2017). Problem Solving from a Mathematical Standpoint. In C. Benő \& F. Joachim (Eds.), Educational Research and Innovation: The Nature of Problem Solving Using Research to Inspire 21st Century Learning: Using Research to Inspire 21st Century Learning (pp. 59-72). Paris: OECD Publishing. https://doi.org/10.1787/9789264273955-en

Ernest, P. (1991). The Philosophy of Mathematics Education. UK: Routledge.

Fan, L., Mailizar, M., Alafaleq, M., \& Wang, Y. (2018). A Comparative Study on the Presentation of Geometric Proof in Secondary Mathematics Textbooks in China, Indonesia, and Saudi Arabia. 53-65. https://doi.org/10.1007/978-3-319-73253-4_3

Goos, M., Stillman, G., \& Vale, C. (2017). Teaching secondary School Mathematics: Research and Practice for the 21st Century. Australia: Allen \& Unwin.

Grigg, S., Perera, H. N., McIlveen, P., \& Svetleff, Z. (2018). Relations among math self efficacy, interest, intentions, and achievement: A social cognitive perspective. Contemporary Educational Psychology, 53, 73-86. https://doi.org/10.1016/j.cedpsych.2018.01.007

Hathaway, D., \& Norton, P. (2018). Understanding Problems of Practice A Case Study in Design Research (J. Spector, M. Bishop, \& D. Ifenthaler, Eds.). USA: Springer. https://doi.org/10.1007/978-3-319-77559-3

Herbst, P., Fujita, T., Halverscheid, S., \& Weiss, M. (2017). The Learning and Teaching of Geometry in Secondary Schools: A Modeling Perspective. New York NY: Routledge. https://doi.org/10.1007/978-3319-98767-5_13

Huang, X., Zhang, J., \& Hudson, L. (2018). Impact of math self-efficacy, math anxiety, and growth mindset on math and science career interest for middle school students: the gender moderating effect. European Journal of Psychology of Education, 1-20. https://oi.org/10.1007/s10212-018-0403-z

Lishinski, A., Yadav, A., Good, J., \& Enbody, R. (2016). Learning to program: Gender differences and interactive effects of students' motivation, goals, and self-efficacy on performance. ACM Conference on International Computing Education Research, 211-220. https://doi.org/10.1145/2960310.2960329

OECD. (2013). PISA 2012 Assessment and Analytical Framework: Mathematics, Reading, Science, Problem Solving and Financial Literacy. Paris: OECD Publishing.

Prawoto, N., \& Basuki, A. T. (2016). Model Analisis Komposisi Pengeluaran Publik terhadap Pertumbuhan Ekonomi dalam Mendukung Good Governance: Studi Empiris Kabupaten Kota di Indonesia Tahun 2011- 2014. Buletin Ekonomi, 14(2), 177-192.

Rahayu, T., \& Alghadari, F. (2019). Identitas Bayangan Konsep Limas: Analisis Terhadap Konsepsi Matematis Siswa. Inomatika: Jurnal Inovasi Matematika, 1(1), 7-20. https://doi.org/10.35438/inomatika.v1i1.134

Romey, W. D. (1970). What is your creativity quotient?. School Science and Mathematics, 70(1), 3-8.

Rosilawati, \& Alghadari, F. (2018). Konsepsi siswa pada suatu bentuk bangun ruang terkait dengan rusuk dan diagonal sisi. Prisma: Jurnal Pendidikan Matematika, 7(2), 164-176. https://doi.org/10.35194/jp.v7i2.459 
Schunk, D. H., \& Dibenedetto, M. K. (2016). Self-Efficacy Theory in Education. In K. R. Wentzel \& D. B. Miele (Eds.), Handbook of Motivation at School (pp. 34-54). UK: Routledge. https://doi.org/10.4324/9781315773384.ch3

Setiadi, D. R., Suryadi, D., \& Mulyana, E. (2017). Didactical Design Enrichment of Angle in Geometry. Journal of Physics: Conference Series, 895(1), 012060. https://doi.org/10.1088/1742-6596/895/1/012060

Silk, K. J., \& Parrott, R. L. (2014). Math anxiety and exposure to statistics in messages about genetically modified foods: Effects of numeracy, math self-efficacy, and form of presentation. Journal of Health Communication, 19(7), 838-852. https://doi.org/10.1080/10810730.2013.837549

Sinclair, N., Bartolini Bussi, M. G., de Villiers, M., Jones, K., Kortenkamp, U., Leung, A., \& Owens, K. (2016). Recent research on geometry education: an ICME-13 survey team report. ZDM - Mathematics Education, 48(5), 691-719. https://doi.org/10.1007/s11858-016-0796-6

Skaalvik, E. M., Federici, R. A., \& Klassen, R. M. (2015). Mathematics achievement and self-efficacy: Relations with motivation for mathematics. International Journal of Educational Research, 72, 129-136. https://doi.org/10.1016/j.ijer.2015.06.008

Street, K. E. S., Malmberg, L. E., \& Stylianides, G. J. (2017). Level, strength, and facet-specific self-efficacy in mathematics test performance. ZDM - Mathematics Education, 49(3), 379-395. https://doi.org/10.1007/s11858-017-0833-0

Sumarna, N., Wahyudin, W., \& Herman, T. (2017). The Increase of Critical Thinking Skills through Mathematical Investigation Approach. Journal of Physics: Conference Series, 812, 1-8. https://doi.org/10.1088/1742-6596/812/1/012067

Wieber, A. E., Evoy, K., McLaughlin, T. F., Derby, K. M., Kellogg, E., Williams, R. L., ... Rinaldi, L. (2017). The effects of a modified direct instruction procedure on time telling for a third grade student with learning disabilities with a brief comparison of interesting and boring formats. Learning Disabilities: A Contemporary Journal, 15(2), 239-248.

Xu, Z., \& Jang, E. E. (2017). The role of math self-efficacy in the structural model of extracurricular technologyrelated activities and junior elementary school students' mathematics ability. Computers in Human Behavior, 68, 547-555. https://doi.org/10.1016/j.chb.2016.11.063

Yeo, J. B. . (2013). The Nature and Development of Processes in Mathematical Investigation. Nanyang Technological University.

Yeo, J. B. W. (2017). Specialising and conjecturing in mathematical investigation. 41st Conference of the International Group for the Psychology of Mathematics Education, 4, 337-344.

Zhang, C. (2017a). An Inquiry into Student Math Self-Efficacy, As Told from the Perspective of Ontario Secondary Teachers. University of Toronto.

Zhang, D. (2017b). Effects of visual working memory training and direct instruction on geometry problem solving in students with geometry difficulties. Learning Disabilities: A Contemporary Journal, 15(1), 117-138. 